\title{
Three new species and one new record of Torrenticolidae (Acari, Hydrachnidia) from Wuyishan with an updated key for Chinese fauna
}

\author{
Xin-Yao GU ${ }^{1}$, Dao-Chao JIN², Jian-Jun GUO ${ }^{3, *}$ \\ ${ }^{1,2,3}$ Institute of Entomology, Guizhou University, Guizhou Provincial Key Laboratory \\ for Plant Pest Management of the Mountainous Region, the Scientific Observing and Experimental \\ Station of Crop Pest in Guiyang, Ministry of Agriculture, \\ P. R. China, Guiyang 550025, P. R. China. \\ *Corresponding author: jjguo@gzu.edu.cn \\ 1Email: agr.xyku18@gzu.edu.cn \\ 2Email: daochaojin@126.com \\ ${ }^{1}$ urn:1sid:zoobank.org:author:305FB81D-C66A-4DF1-984A-3B5E3A8FB7BA \\ ${ }^{2}$ urn:lsid:zoobank.org:author:FC06EF2C-1B36-4BFB-9E33-D9AF34725F40 \\ ${ }^{3}$ urn:1sid:zoobank.org:author:00048ADA-2A66-4317-925F-DC97D1749511
}

\begin{abstract}
New data of Torrenticolidae Piersig, 1902 are presented in this paper from Wuyishan National Nature Reserve, P. R. China. Three new species, Torrenticola suptilisrostrum Gu \& Guo sp. nov., Torrenticola spinextension Gu \& Guo sp. nov. and Torrenticola wuyiensis Gu \& Guo sp. nov. are described and illustrated in detail, and one new record for Chinese fauna is given, Torrenticola dentifera Wiles, 1991, which was originally described from Malaysia. In addition, an updated key is provided to all species of Torrenticolidae in China.
\end{abstract}

Keywords. Hydrachnidia, Torrenticolidae, new species, new record, Chinese fauna.

Gu X.-Y., Jin D.-C. \& Guo J.-J. 2020. Three new species and one new record of Torrenticolidae (Acari, Hydrachnidia) from Wuyishan with an updated key for Chinese fauna. European Journal of Taxonomy 625: 1-23. https://doi.org/10.5852/ejt.2020.625

\section{Introduction}

Torrenticolidae Piersig, 1902 is diverse in species, and distributes all six zoogeographic kingdoms worldwide. To date, there are more than 600 species all over the world, while only 28 species from China, which shows a big gap between the international and Chinese research levels (Gu \& Guo 2019).

China is the third biggest country in the world, and rich in animal species. During a survey of water mites, four species are added to Chinese fauna from Wuyishan National Nature Reserve, of which three species are described and illustrated as new to science, Torrenticola suptilisrostrum $\mathrm{Gu} \&$ Guo sp. nov., Torrenticola spinextension $\mathrm{Gu} \&$ Guo sp. nov. and Torrenticola wuyiensis Gu \& Guo sp. nov., and 
one new record for Chinese fauna is given, Torrenticola dentifera Wiles, 1991, which was originally described from Malaysia.

\section{Material and methods}

Water mites were collected, preserved, cleaned and mounted following Jin (1997). Abbreviations used for morphological terms follow Jin (1997), Goldschmidt (2007). Abbreviations used for the chaetotaxy and nomenclature of glandularia used follows Jin (1997). Abbreviations of dorsal plate arrangements used follows Wiles (1997). Abbreviations used for institutional abbreviations follow Zhang(2018).

\section{Abbreviations used for morphological terms}

$\begin{array}{ll}\mathrm{aL} & =\text { apical length } \\ \mathrm{Ap} & =\text { anal pore } \\ \mathrm{bs} & =\text { basal segment of chelicera } \\ \mathrm{Cx}-\mathrm{I}-\mathrm{Cx}-\mathrm{IV} & =\text { coxae I-IV } \\ \mathrm{dL} & =\text { dorsal length } \\ \mathrm{Gf} & =\text { Genital field } \\ \mathrm{I}-\mathrm{L}-1-6, \text { etc. } & =\text { first leg segments 1-6, etc. } \\ \mathrm{L} & =\text { length } \\ \mathrm{mL} & =\text { medial length } \\ \mathrm{P}-1-5 & =\text { palp segment } 1-5 \\ \mathrm{vL} & =\text { ventral length } \\ \mathrm{W} & =\text { width }\end{array}$

Abbreviations used for the chaetotaxy and nomenclature of glandularia

$A_{2} \quad=$ postantennal glandularia

$D_{1}-D_{4} \quad=$ dorsoglandularia $1-4$

$E_{2}, E_{4} \quad=$ epimeroglandularia 2,4

$L_{1}-L_{4} \quad=$ lateroglandularia $1-4$

$\mathrm{O}_{2} \quad=$ postocularia

$V_{1}^{2}-V_{4} \quad=$ ventroglandularia $1-4$

\section{Abbreviations used for dorsal plate arrangements}

$2+1=$ three plates: two anterior platelets and a single large dorsal plate, the posterior platelets are fused to the large dorsal plate

$4+1=$ five plates: four anterior platelets and a single large dorsal plate

$2+2 \mathrm{p}+1=$ five plates with the posterior pair of anterior platelets partially fused to the dorsal plate.

All measurements are given in $\mu \mathrm{m}$, length of palp and leg segments are given as dorsal length, following Goldschmidt (2007). Measurements for paratype are given in brackets. All the specimens examined are deposited in GUGC.

\section{Institutional abbreviations}

GUGC = Institute of Entomology, Guizhou University, Guiyang, China 


\section{Results}

Class Arachnida Lamarck, 1801

Family Torrenticolidae Piersig, 1902

Genus Torrenticola Piersig, 1896

Torrenticola suptilisrostrum Gu \& Guo sp. nov.

urn:lsid:zoobank.org:act:EEBC35EF-7EFE-4FEA-978D-3D4D2D869986

Figs $1-4$
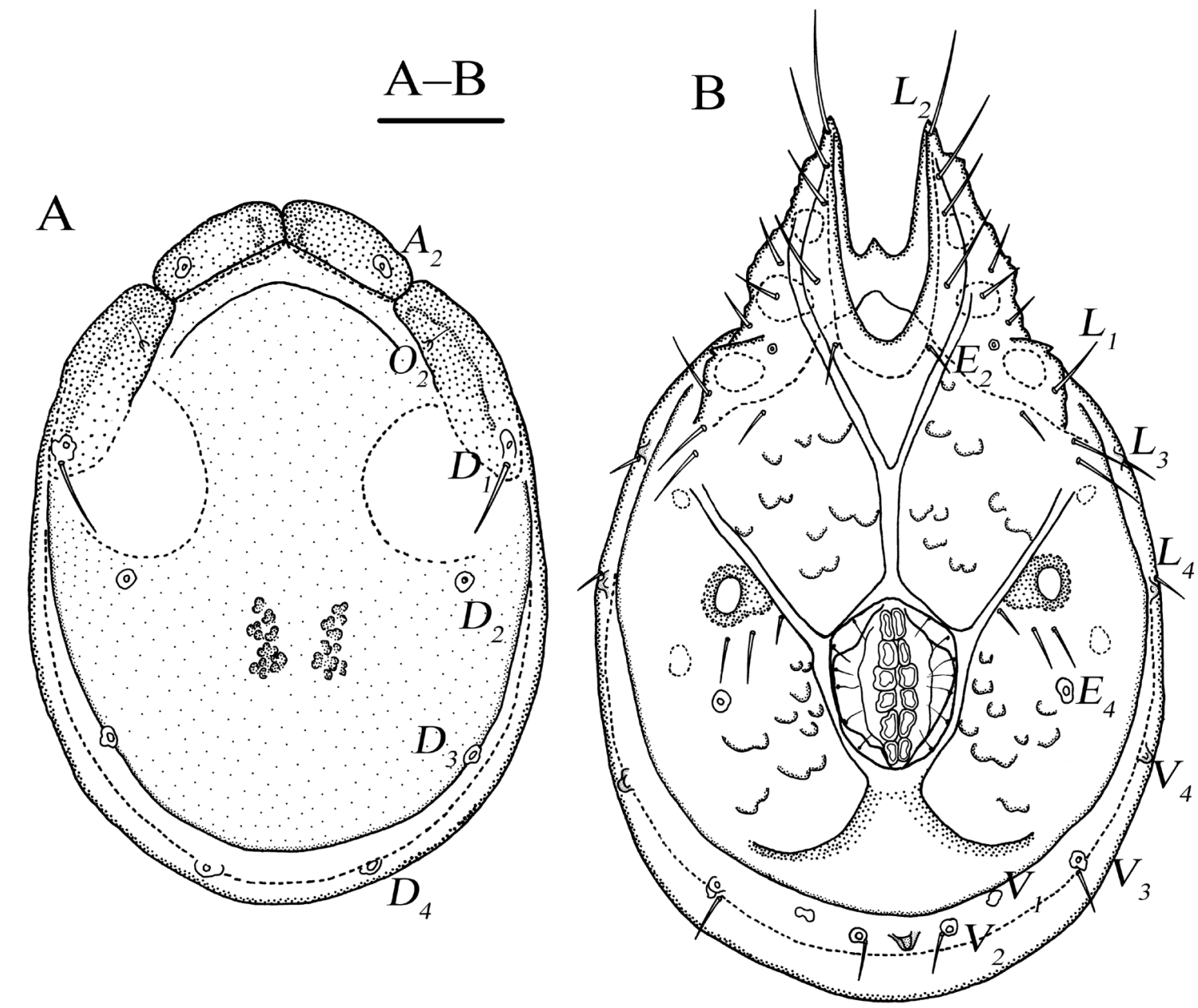

C

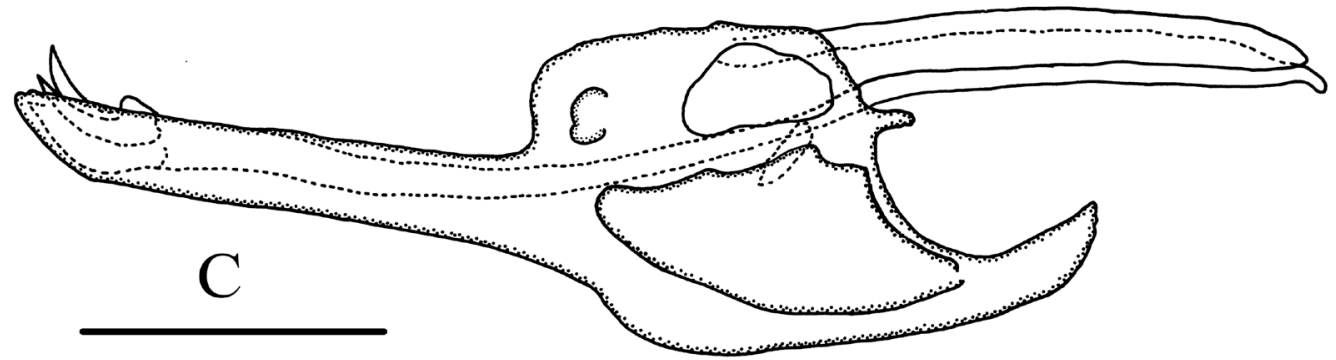

Fig. 1. Torrenticola suptilisrostrum Gu \& Guo sp. nov., §̂, holotype (FJ-TO-20180801). A. Dorsal view. B. Ventral view. C. Infracapitulum and chelicera. Scale bars $=100 \mu \mathrm{m}$. 


\section{Diagnosis}

Idiosoma elliptical; dorsal plate arrangement: $2+2 p+1$; dorsal plate with a colour pattern, hour-glassshaped with pale "shoulder-patches"; infracapitular bay V-shaped; $E_{4}$ on the same line with the $4^{\text {th }}$ pair of acetabula; infracapitular rostrum extremely slender and slightly curved towards the dorsum.

\section{Etymology}

The specific name is from the Latin words "suptilis" (slender) and "rostrum" (beak), referring to the slender rostrum; used as a noun in apposition.

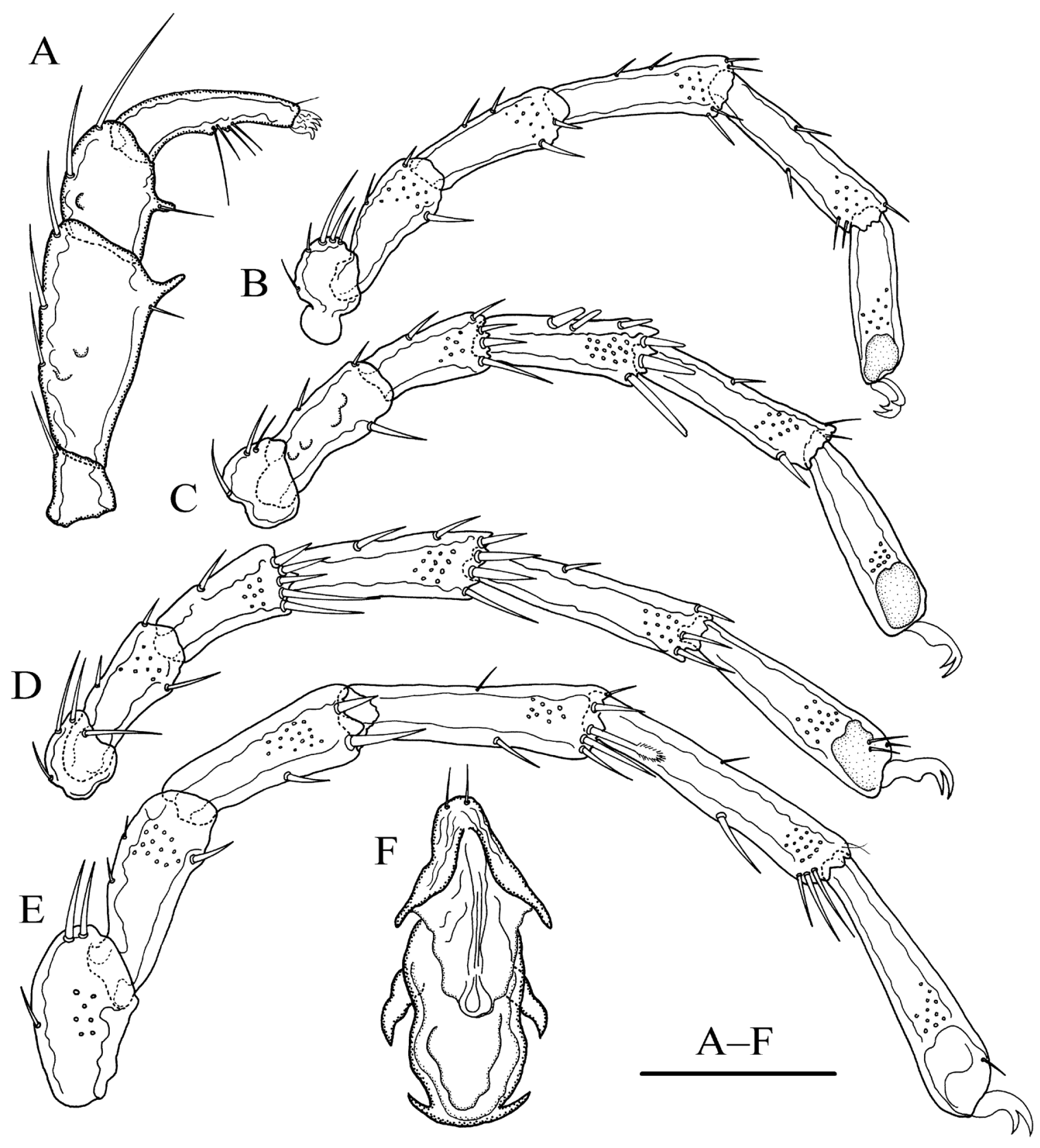

Fig. 2. Torrenticola suptilisrostrum Gu \& Guo sp. nov., §, holotype (FJ-TO-20180801). A. Palp, lateral view. B. leg-I. C. leg-II. D. leg-III. E. leg-IV. F. Ejaculatory complex. Scale bar $=100 \mu \mathrm{m}$. 


\section{Material examined}

Holotype

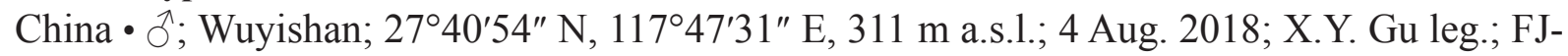
TO-20180801.

\section{Paratypes}

China 1 đ̂, 1 ㅇ; same collection data as for holotype; FJ-TO-20180802 to FJ-TO-20180803.
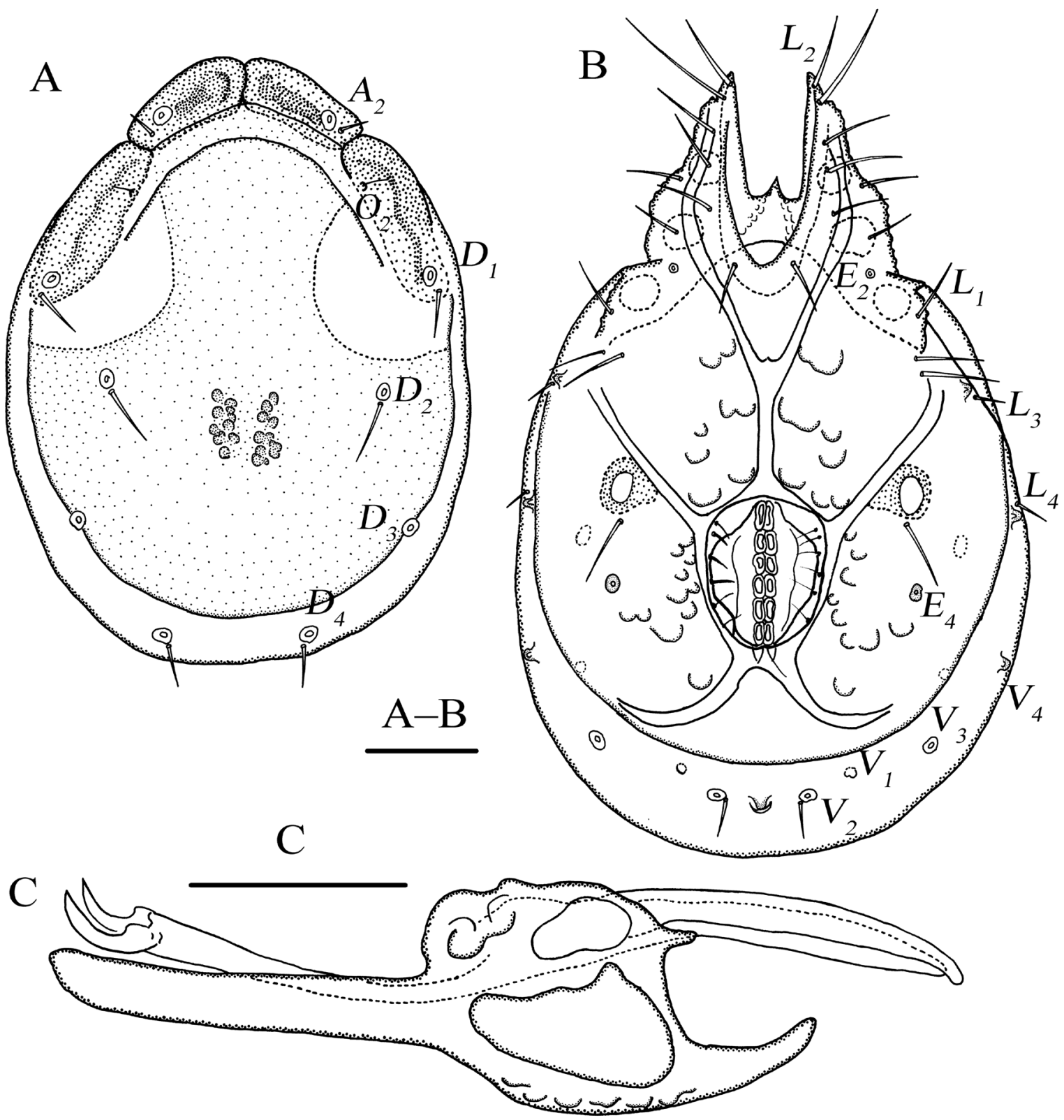

Fig. 3. Torrenticola suptilisrostrum Gu \& Guo sp. nov., ${ }^{+}$, paratype (FJ-TO-20180803). A. Dorsal view. B. Ventral view. C. Infracapitulum and chelicera. Scale bars $=100 \mu \mathrm{m}$. 


\section{Description}

Male ( $\mathbf{n}=\mathbf{2})$

Body. Idiosoma elliptical, L/W ratio 1.5 (1.5) (Fig. 1B). Dorsal plate arrangement: $2+2 \mathrm{p}+1$; dorsal plate with colour pattern, hour-glass-shaped with pale "shoulder-patches" (Fig. 1A). Infracapitular bay V-shaped, Cx-II-III mL relatively long; $E_{4}$ on same line with $4^{\text {th }}$ pair of acetabula; $V_{1}$ anterior to $V_{2}, V_{2}$ almost at same level of Ap (Fig. 1B). Gnathosoma dorsal apodeme short and blunt, ventral apodeme long and wide, rostrum long, extremely slender, curved slightly to dorsum (Fig. 1C). Palp (Fig. 2A): P-1 long, with one dorsal seta; P-2 with three dorsal setae and one ventral seta on ventrodistal prolongation, which is slender and curved towards distal; P-3 with two dorsal setae and one ventral seta on ventrodistal prolongation; P-4 with two developed ventral extensions, bearing one long and three short setae. Legs I-IV as shown in Fig. 2B-E. Ejaculatory complex with well developed anterior keel and proximal arms (Fig. 2F).

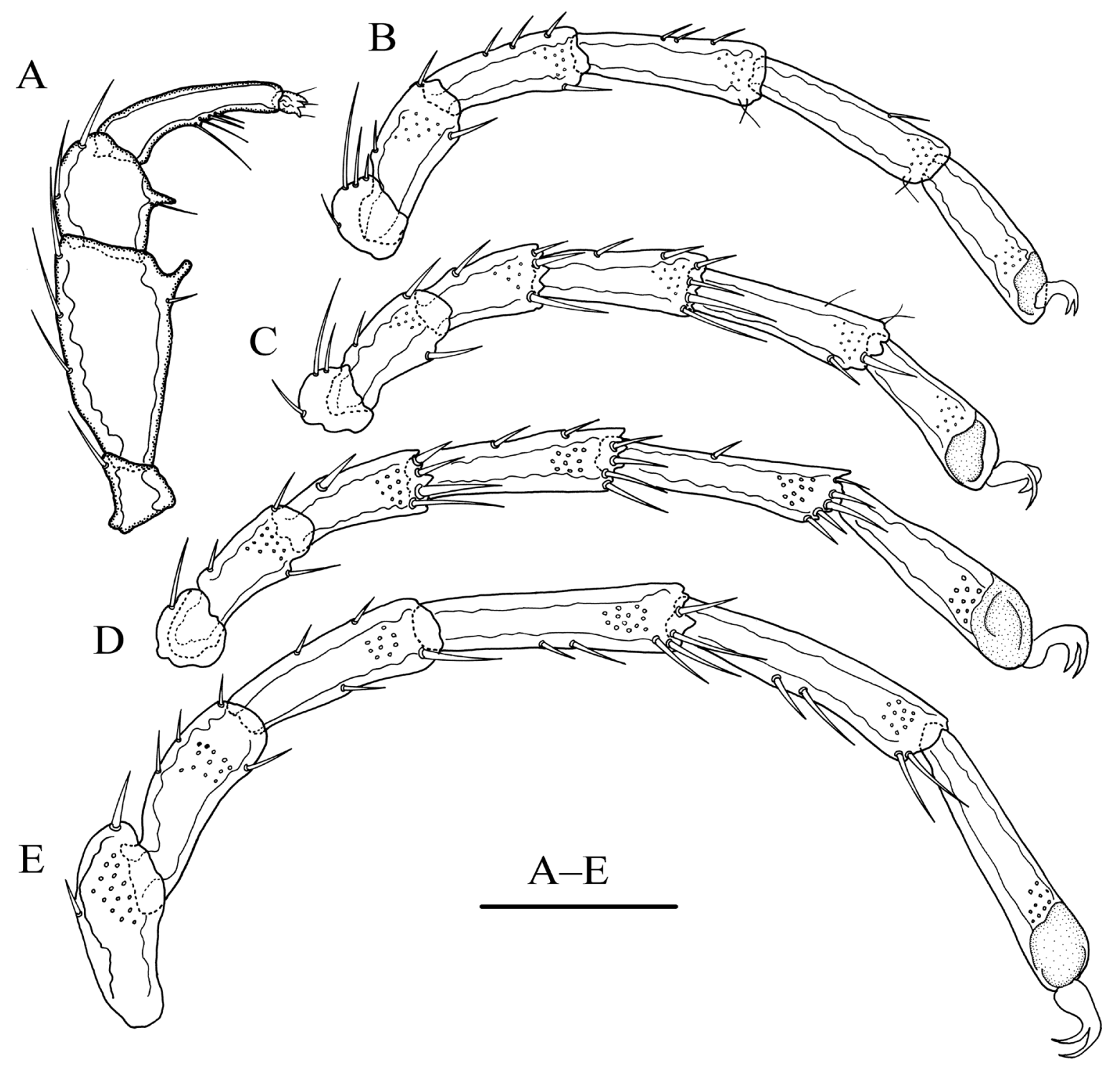

Fig. 4. Torrenticola suptilisrostrum Gu \& Guo sp. nov., + , paratype (FJ-TO-20180803). A. Palp, lateral view. B. leg-I. C. leg-II. D. leg-III. E. leg-IV. Scale bar $=100 \mu \mathrm{m}$. 
Measurements. Idiosoma L 688 (698), W 462 (454); dorsal shield L 563 (563), W 418 (402); dorsal plate L 509 (529), frontal platelets L 122 (115), shoulder platelets L 169 (168). Infracapitular bay depth 160 (170); Cx-1 L 207 (204), mL 104 (105), Cx-II-III mL 103 (99); Gf L 138 (137), W 105 (112), distance between Gf and Ap 118 (133). Gnathosoma vL 351 (359), dL 277 (280), chelicera bs L 307 (376), claw L 39 (44). Ejaculatory complex (Fig. 2f), L 177 (166), aL 123 (112), W 85 (78). L of palp segments: P-1, 40 (42); P-2, 114 (121); P-3, 61 (53); P-4, 94 (103); P-5, 16 (13). L of leg segments: I-L-1-6: 39 (35), 82 (78), 85 (83), 99 (102), 106 (112), 92 (94); II-L-1-6: 53 (34), 95 (86), 67 (74), 94 (90), 104 (109), 98 (108); III-L-1-6: 44 (43), 90 (59), 76 (84), 112 (109), 112 (128), 128 (129); IV-L-1-6: 94 (112), 105 (93), 107 (113), 128 (144), 143 (150), 137 (121).

\section{Female $(n=1)$}

BoDy. Body features same as for the male.

Measurements. Idiosoma L 687, W 460. Dorsal shield L 558, W 418; dorsal plate L 512, frontal platelets L 120, shoulder platelets L 175. Infracapitular bay L 159; Cx-1 L 194, mL 89, Cx-II-III mL 105. Gf L 135, W 104, distance between Gf and Ap 125. Gnathosoma vL 330, dL 256, chelicera bs L 338, claw L 66. L of palp: P-1, 35; P-2, 127; P-3, 62; P-4, 118; P-5, 19. L of leg segments: I-L-1-6: 34, 83, 81, 95, 107, 95; II-L-1-6: 34, 54, 69, 93, 104, 96; III-L-1-6: 44, 58, 74, 107, 123, 122; IV-L-1-6: 105, 90, 110, $142,150,141$.

\section{Distribution}

China (Wuyishan).

\section{Habitat}

Streamlet.

\section{Remarks}

The new species, Torrenticola suptilisrostrum sp. nov., is similar to T. fagei E. Angelier, 1949 (Martin 2009). The new species shares the character of an infracapitular rostrum extremely slender and slightly curved towards the dorsum with $T$. fagei. However, T. suptilisrostrum sp. nov. differs from the latter by $E_{4}$ on the same line with the $4^{\text {th }}$ pair of acetabula $\left(5^{\text {th }}\right.$ in $T$. fagei); dorsal plate $2+2 \mathrm{p}+1$ (dorsal plate $4+1$ in T.fagei); $\mathrm{P}-2$ robust and compact (P-2 relatively thin and long in T. fagei).

Torrenticola spinextension $\mathrm{Gu} \&$ Guo sp. nov. urn:1sid:zoobank.org:act:2CAE5F0A-B477-4CE0-B712-3F609A7B6284

Figs $5-8$

\section{Diagnosis}

Idiosoma elliptical; dorsal plate arrangement: $4+1$; infracapitular bay narrow $\mathrm{U}$-shaped; $V_{l}$ anterior to $V_{2}, V_{2}$ almost at the same level of Ap; P-2 with a laterally compressed, apically serrated and spine-like ventrodistal extension.

\section{Etymology}

Named after the shape of ventral extension on P-2. The specific name is from Latin words "spina" (thorn), there we used "spin-" and "extension" (extension or prolongation); used as a noun in apposition. 


\section{Material examined}

\section{Holotype}

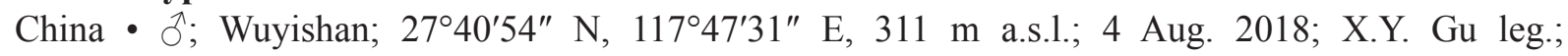
FJ-TO-20180804.

\section{Paratype}

China $\bullet 1$ \%; same collection data as for holotype; FJ-TO-20180805.

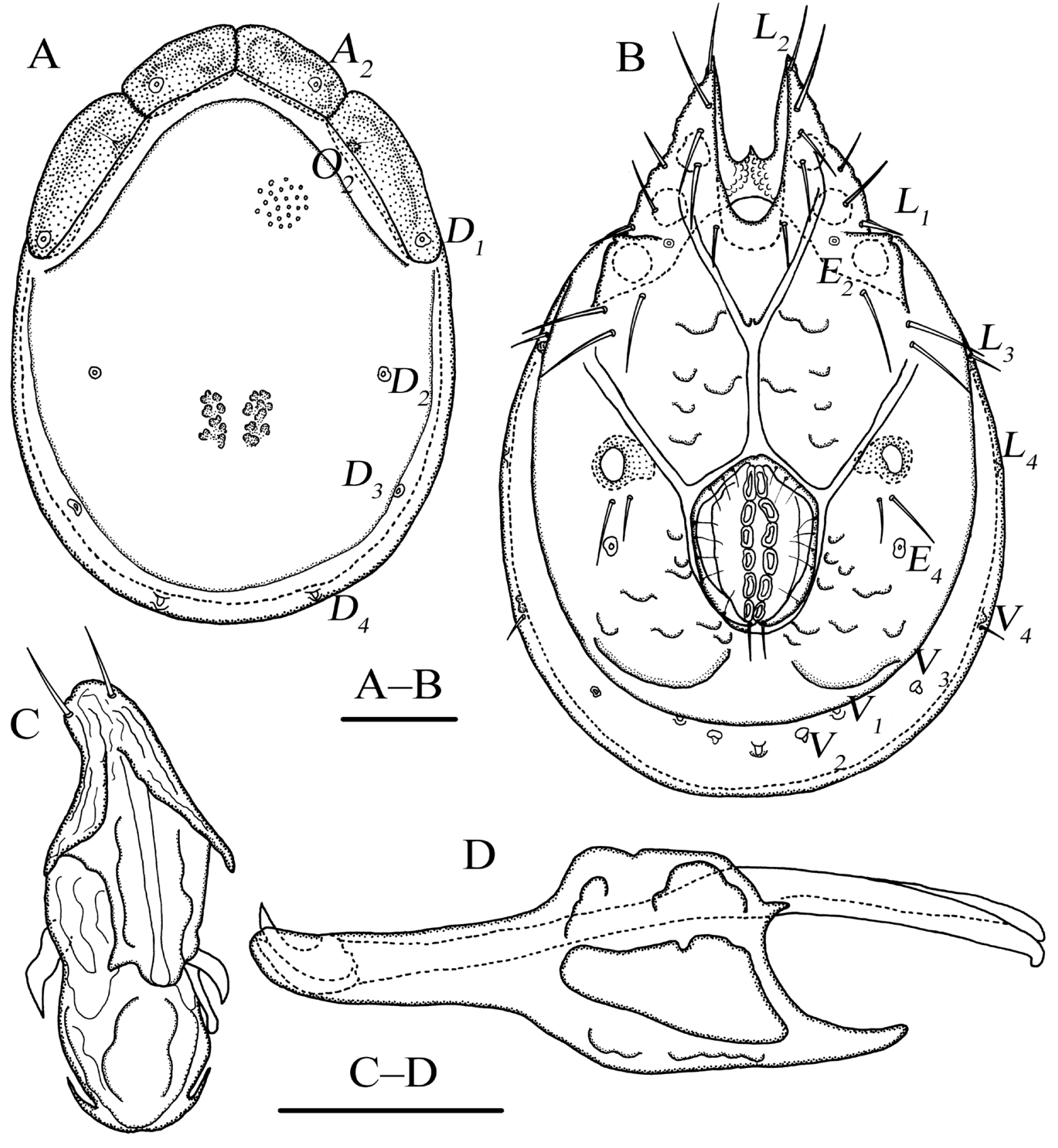

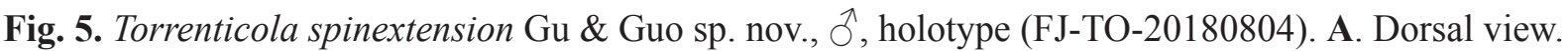
B. Ventral view. C. Ejaculatory complex. D. Infracapitulum and chelicera. Scale bars $=100 \mu \mathrm{m}$. 


\section{Description}

Male $(\mathbf{n}=\mathbf{1})$

Body. Idiosoma elliptical, L/W ratio 1.5 (Fig. 5B). Dorsal plate arrangement: 4+1 (Fig. 5A). Infracapitular bay U-shaped, Cx-II-III $\mathrm{mL}$ relatively long; $E 4$ on same line with $4^{\text {th }}$ pair of acetabula; $V_{1}$ anterior to $V_{2}, V_{2}$ slightly rostral to Ap (Fig. 5B). Ejaculatory complex with well-developed anterior keel and proximal arms (Fig. 5C). Gnathosoma dorsal apodeme short and pointed, ventral apodeme long and wide (Fig. 5D). Palp: P-1 long, with one dorsal seta; P-2 short and wide, with three dorsal setae, laterally compressed, apically serrated and spine-like ventrodistal extension, one very short seta laterally at the base of extension; P-3 with two dorsal setae, and one ventral seta on ventral prolongation; P-4 with one tiny dorsal seta and two ventral extensions, bearing one long and three short setae (Fig. 6A). Legs I-IV as shown in Fig. 6B-E: the claw of Leg-I damaged.

Measurements. Idiosoma L 635, W 429. Dorsal shield L 520, W 479, dorsal plate L 479, frontal platelets L 104, shoulder platelets L 157. Infracapitular bay depth 136; Cx-I L 228, mL 92, Cx-II-III mL 110; Gf L 140, W 112, distance between Gf and Ap 108. Gnathosoma vL 296, dL 230, chelicera bs L 305, claw L

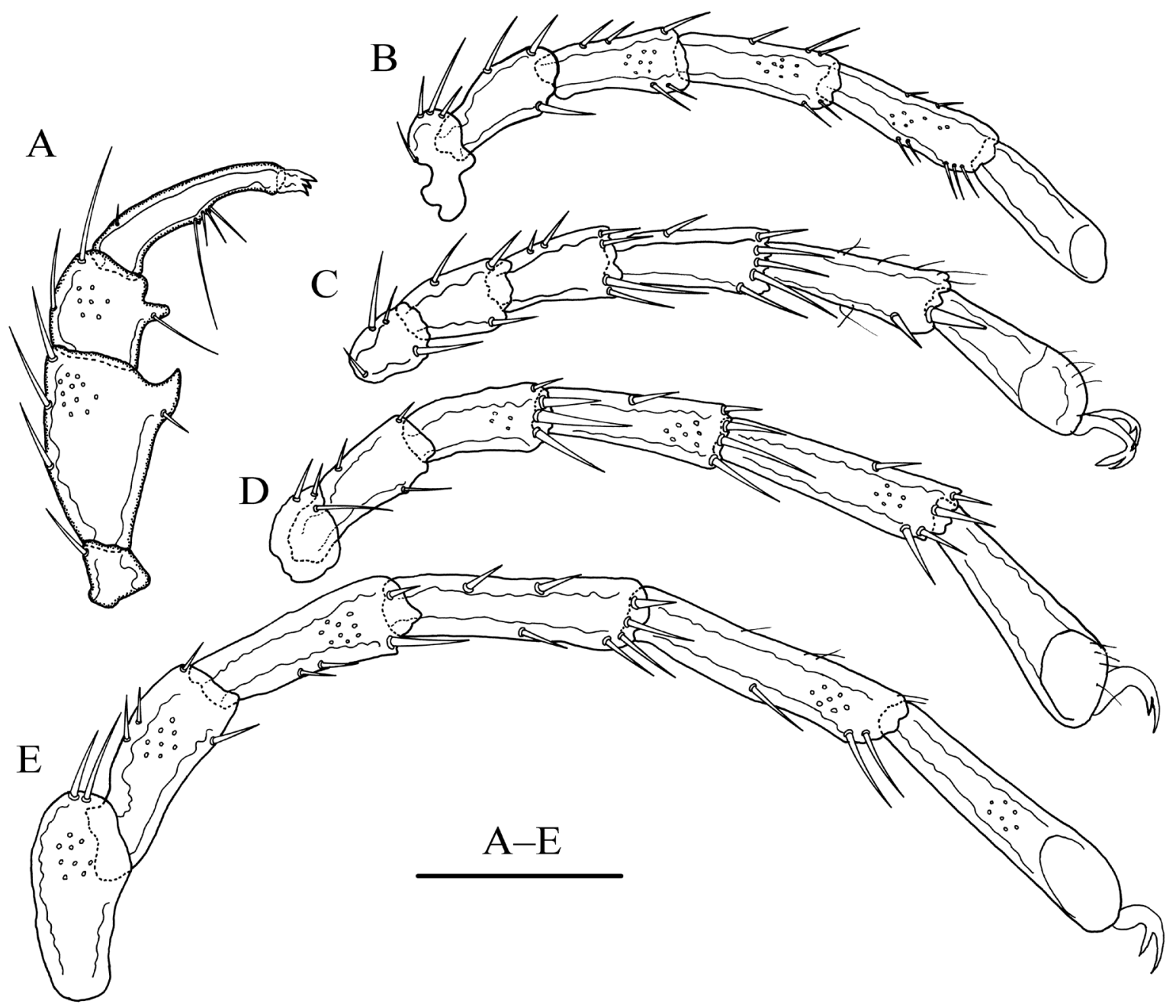

Fig. 6. Torrenticola spinextension Gu \& Guo sp. nov., §, holotype (FJ-TO-20180804). A. Palp, lateral view. B. leg-I. C. leg-II. D. leg-III. E. leg-IV. Scale bar $=100 \mu \mathrm{m}$. 
50. Ejaculatory complex (Fig. 5C), L 206, aL 139, W 92. L of palp segments: P-1, 32; P-2, 102; P-3, 50; P-4, 101; P-5, 22. L of leg segments: I-L-1-6: 41, 86, 72, 84, 90, 91; II-L-1-6: 37, 82, 65, 82, 95, 109; III-L-1-6: 49, 82, 73, 100, 114, 130; IV-L-1-6: 102, 86, 106, 123, 143, 155.

Female $(n=1)$

BoDy. Body features same as male except: dorsal plate with reddish or dark purple pattern at anterior and posterior parts; location of muscle scars posterior to male; $E_{4}$ on same line with $5^{\text {th }}$ pair of acetabula; line of primary sclerotization farther ahead $D_{3}$ and $D_{4}$.

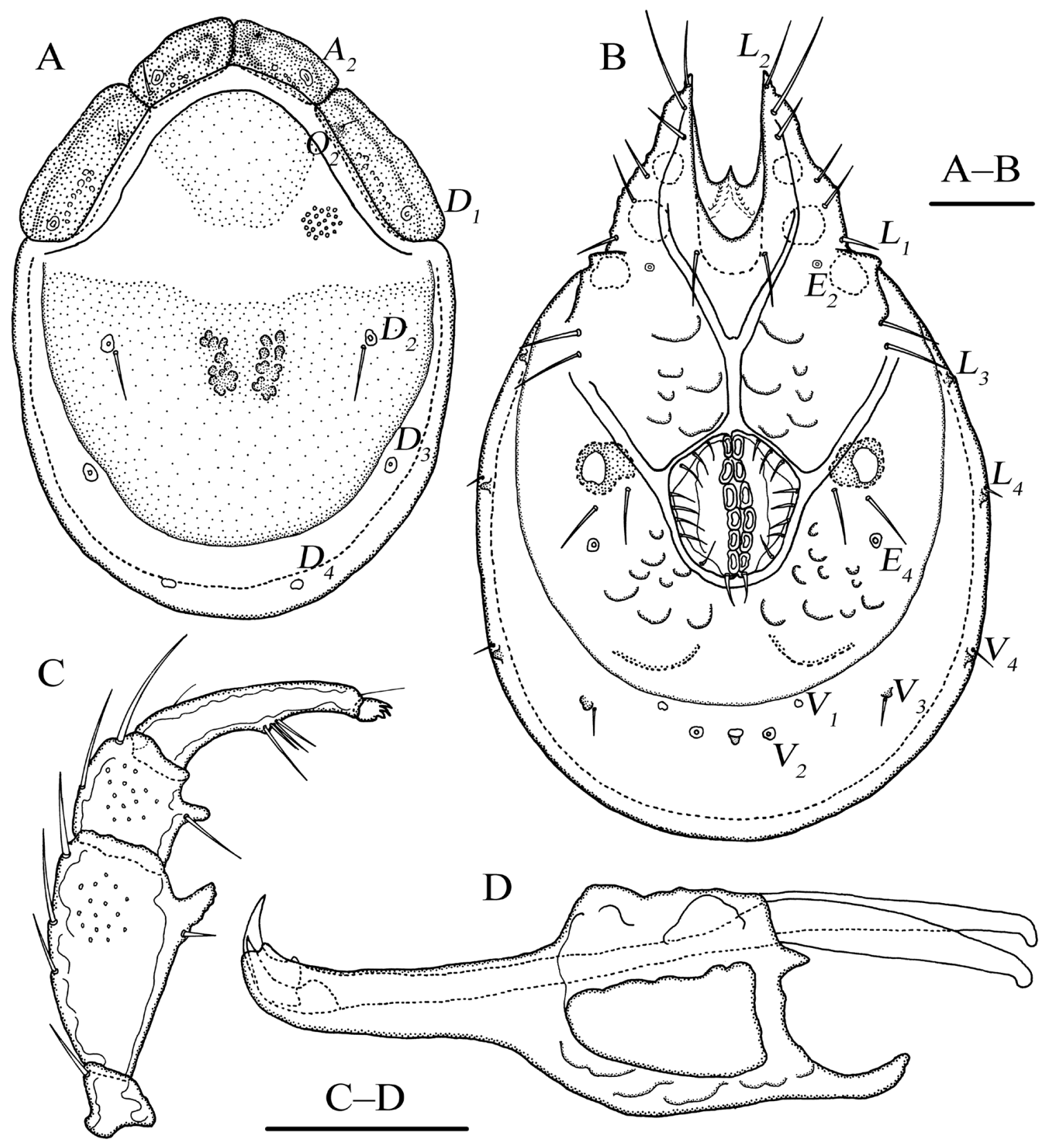

Fig. 7. Torrenticola spinextension Gu \& Guo sp. nov., + , paratype (FJ-TO-20180805). A. Dorsal view. B. Ventral view. C. Palp, lateral view. D. Infracapitulum and chelicera. Scale bars $=100 \mu \mathrm{m}$. 
Measurements. Idiosoma L 731, W 487. Dorsal shield L 577, W 427; dorsal plate L 538; frontal platelets L 117; shoulder platelets L 175. Infracapitular bay depth 161; Cx-I L 267, mL 106, Cx-II-III mL 69; Gf L 150, W 122, distance between Gf and Ap 155. Gnathosoma vL 330, dL 256, chelicera bs L 338, claw L 66. L of palp: P-1, 35; P-2, 127; P-3, 62; P-4, 118; P-5, 19. L of leg segments: I-L-1-6: 39, 64, 78, 95, 98, 96; II-L-1-6: 36, 85, 66, 89, 105, 118; III-L-1-6: 45, 71, 79, 108, 123, 135; IV-L-1-6: 123, 98, 114, $148,157,158$.

\section{Distribution}

China (Wuyishan).

\section{Habitat}

Streamlet.

\section{Remarks}

By having a laterally compressed, apically serrated and spine-like ventrodistal extension on P-2, and one very short seta laterally at the base of extension, this new species is similar to T. borneoensis Pešić \& Smit, 2014 (Pešić \& Smit 2014). But there are obvious differences: dorsal plate arrangement is $4+1$ in T. spinextension ( $2+1$ in T. borneoensis); ventral extension of P-3 is smooth in T. spinextension (serrate in T. borneoensis); two ventral extensions on P-4 are close to each other in T. spinextension (markedly apart from each other in T. borneoensis).

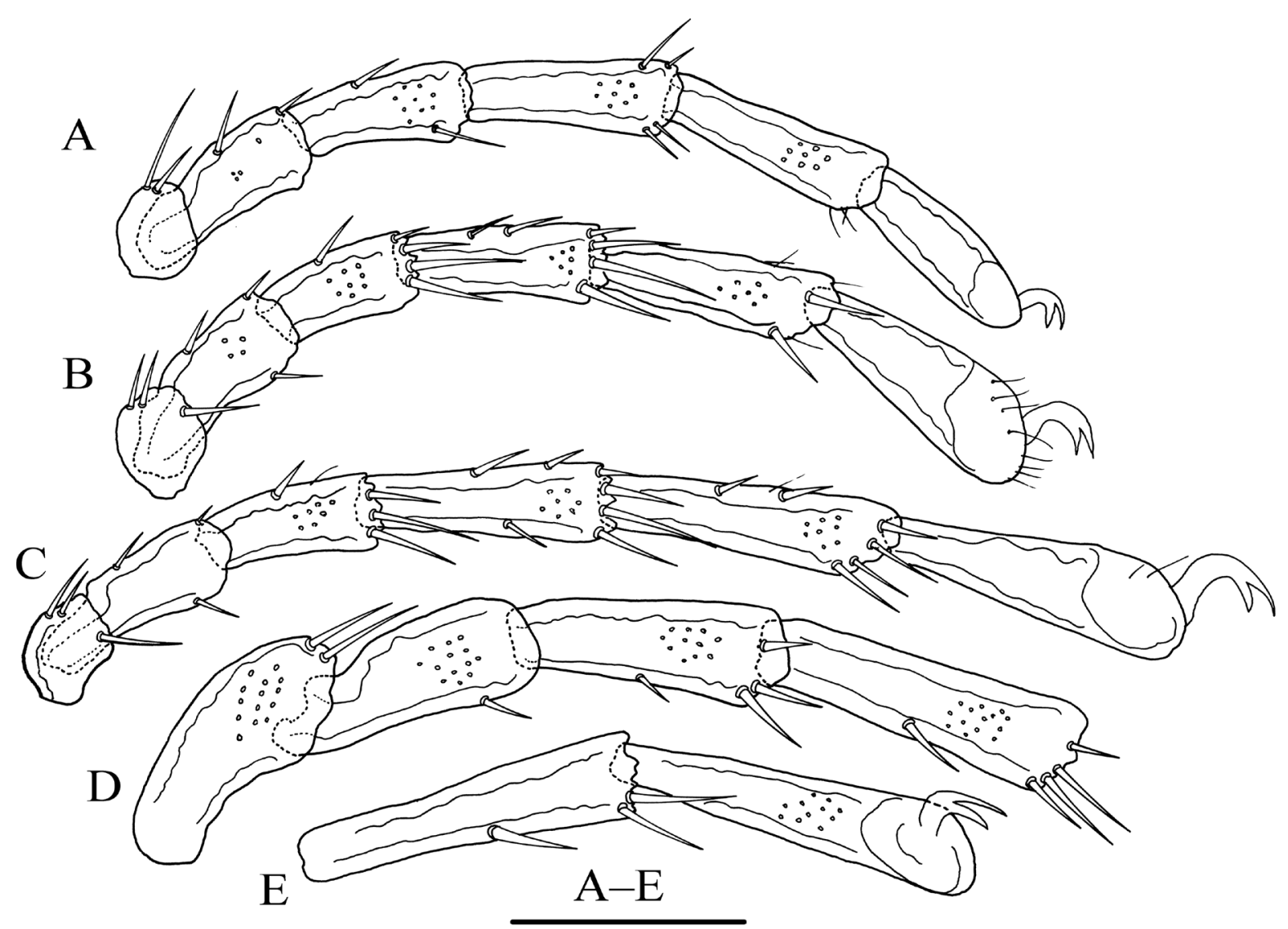

Fig. 8. Torrenticola spinextension Gu \& Guo sp. nov., +, paratype (FJ-TO-20180805). A. leg-I. B. legII. C. leg-III. D. leg-IV-1-4. E. leg-IV-5-6. Scale bar $=100 \mu \mathrm{m}$. 
Torrenticola wuyiensis Gu \& Guo sp. nov.

urn:1sid:zoobank.org:act:69E7FE0A-89D6-4CF0-8E20-7E007FA65B62

Figs 9-12

\section{Diagnosis}

Idiosoma elliptical; dorsal plate arrangement: $2+2 p+1$, posterior pair of anterior platelets half fused to dorsal plate; infracapitular bay wide U-shaped; $E_{4}$ on same line with $5^{\text {th }}$ pair of acetabula.

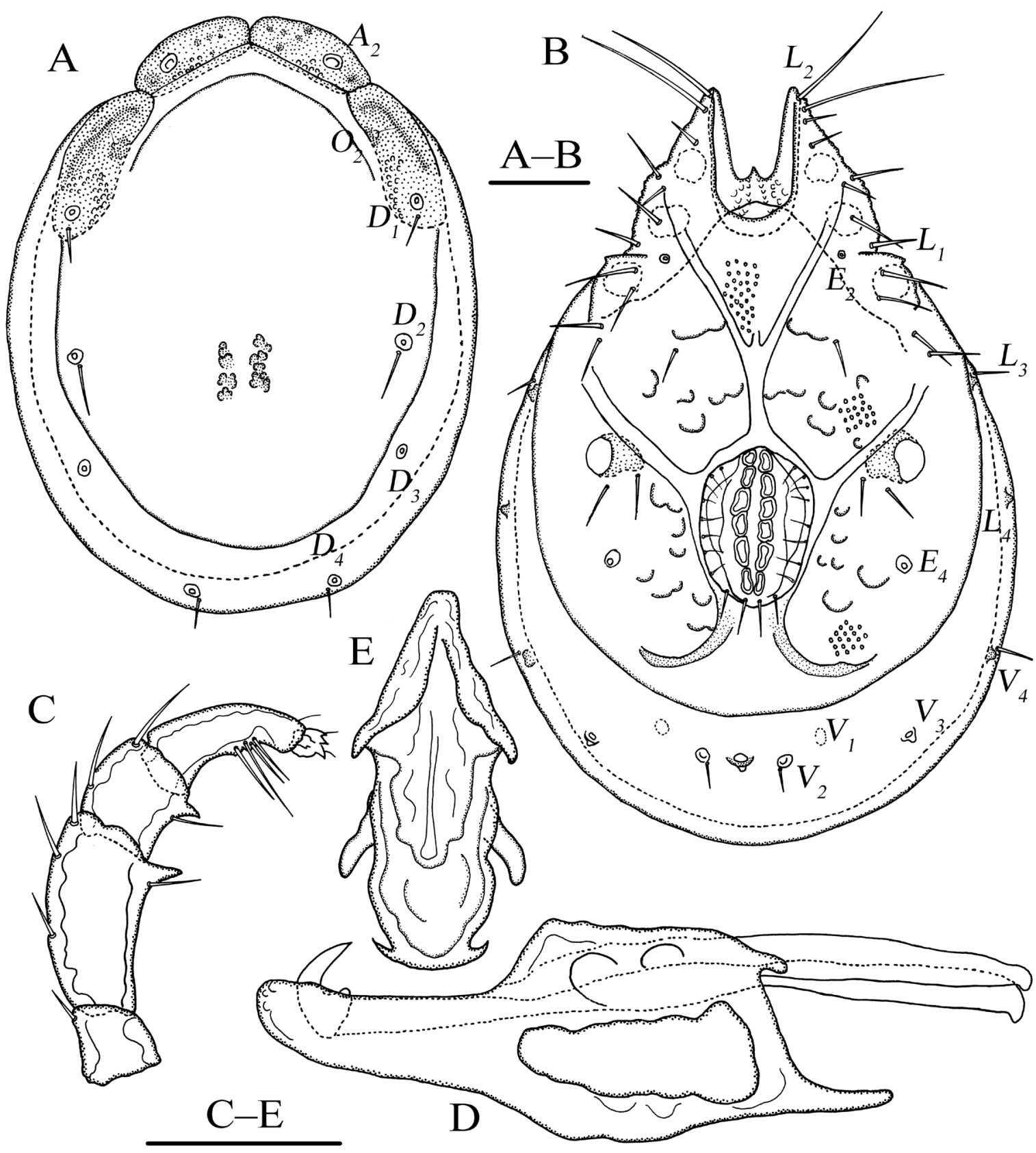

Fig. 9. Torrenticola wuyiensis Gu \& Guo sp. nov., §̂, holotype (FJ-TO-20180807). A. Dorsal view. B. Ventral view. C. Palp, lateral view. D. Infracapitulum and chelicera. E. Ejaculatory complex. Scale bars $=100 \mu \mathrm{m}$. 
GU X.-Y. et al., New species and new record of Torrenticolidae from China

\section{Etymology}

This new species is named after Wuyishan (Wuyi Mountain), where the new species was collected.

\section{Material examined}

\section{Holotype}

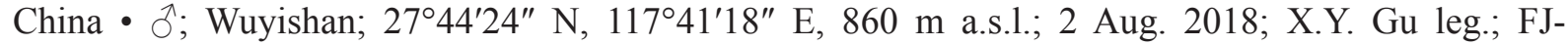
TO-20180807.

\section{Paratypes}

China 1 Ô, 4 q $९$; same collection data as for holotype; FJ-TO-20180808 to FJ-TO-20180812.

\section{Description}

Male ( $\mathrm{n}=2)$

Body. Idiosoma elliptical, L/W ratio 1.44 (1.38) (Fig. 9B). Dorsal plate arrangement: 2+2p+1 (Fig. 9A). Infracapitular bay wide U-shaped, Cx-II-III $\mathrm{mL}$ relatively short; $E_{4}$ on same line with $5^{\text {th }}$ pair of acetabula; $V_{1}$ anterior to $V_{2}, V_{2}$ almost at same level of Ap (Fig. 9B). Gnathosoma dorsal apodeme short, ventral

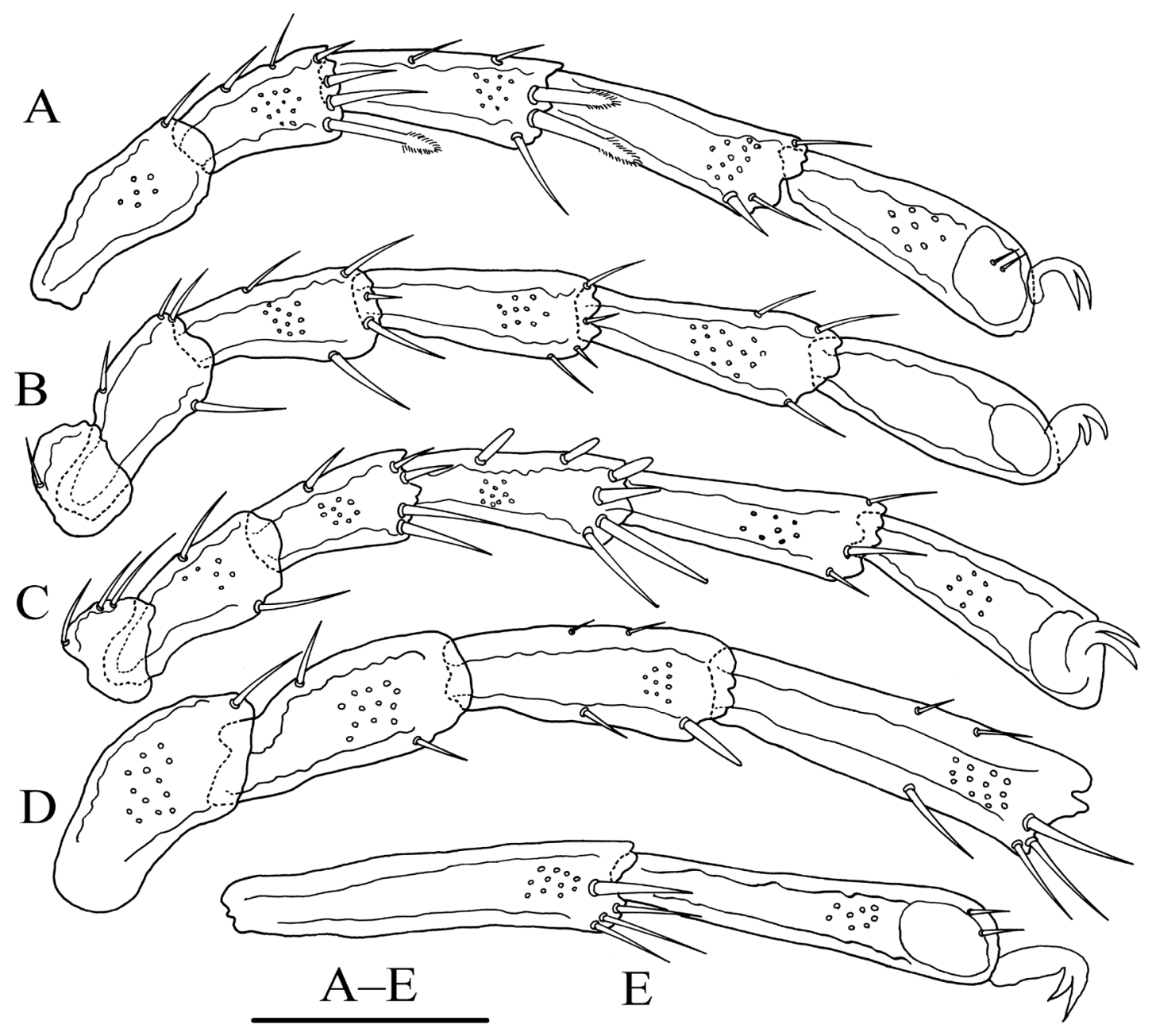

Fig. 10. Torrenticola wuyiensis Gu \& Guo sp. nov., $\hat{\jmath}$, holotype (FJ-TO-20180807). A. leg-I-2-6. B. leg-II. C. leg-III. D. leg-IV-1-4. E. leg-IV-5-6. Scale bar $=100 \mu \mathrm{m}$. 
apodeme long, rostrum curved slightly to ventrum (Fig. 9D). Ejaculatory complex with well developed anterior keel and proximal arms (Fig. 9E). Palp: P-1 short, with one dorsal seta; P-2 with three dorsal setae, one ventral seta at base of sharp ventral prolongation; P-3 with two dorsal setae, one ventral seta on sharp ventral prolongation; P-4 with two ventral extensions, bearing four setae (Fig. 9C). Legs I-IV showed as Fig. 10.

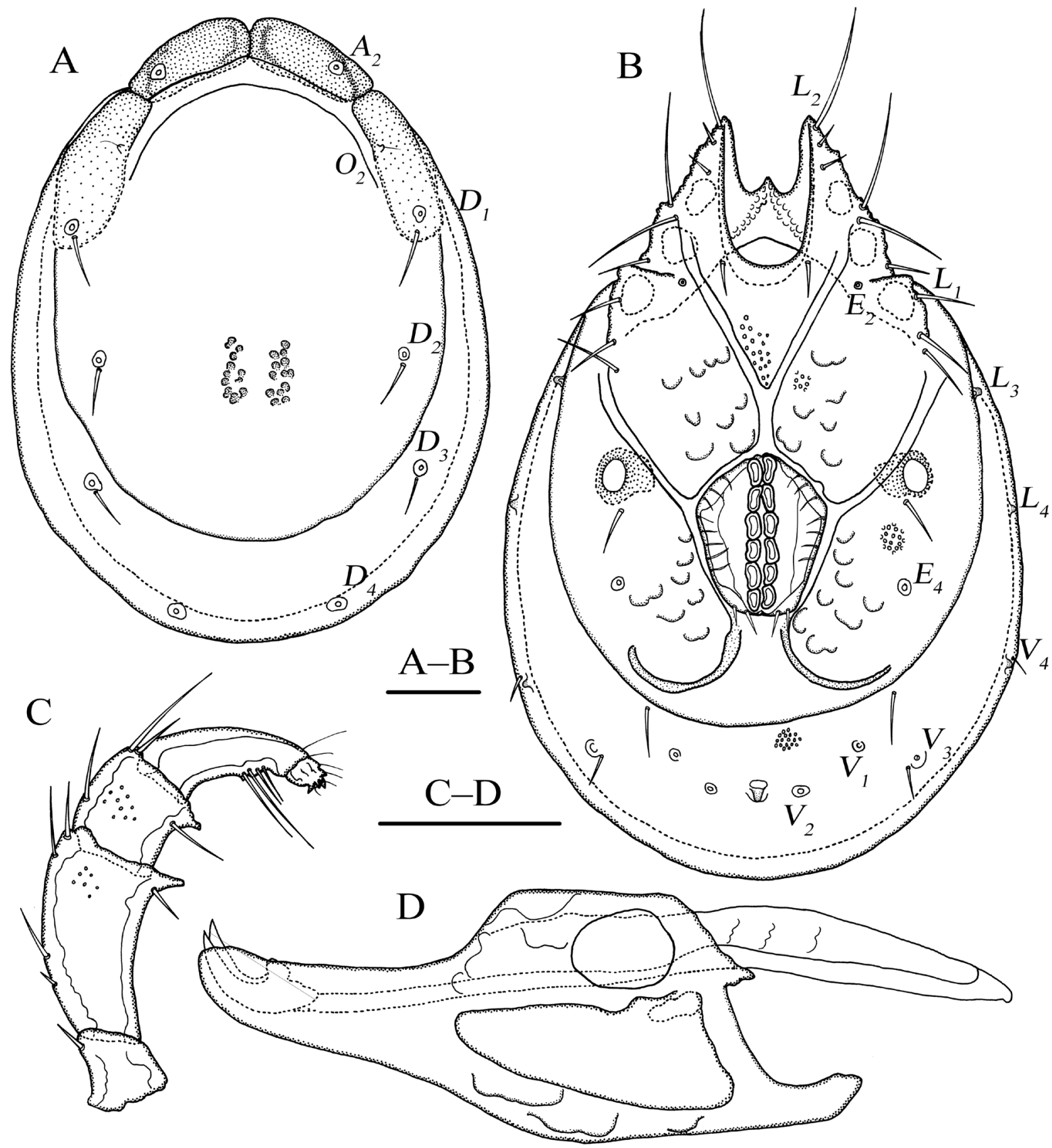

Fig. 11. Torrenticola wuyiensis Gu \& Guo sp. nov., +, paratype (FJ-TO-20180812). A. Dorsal view. B. Ventral view. C. Palp, lateral view. D. Infracapitulum and chelicera. Scale bars $=100 \mu \mathrm{m}$. 
Measurements. Idiosoma L 745 (746), W 514 (539); dorsal shield L 607 (614), dorsal plate L 568 (578), frontal platelets L 127 (132). Infracapitular bay L 128 (154); Cx-1 L 207 (204), mL 132 (113), Cx-II-III mL 73 (87); Gf L 158 (162), W 100 (109), distance between Gf and Ap 158 (144). Gnathosoma vL 331 (341), dL 252 (274), chelicera bs L 352 (320), claw L 49 (67). Ejaculatory complex (Fig. 13E), L 195 (221), aL 146 (160) width 96 (113). L of palp segments: P-1, 44 (40); P-2, 111 (98); P-3, 61 (60); P-4, 91 (83); P-5, 19 (20). L of leg segments: I-L-1-6: - (43); 96 (92), 78 (91), 100 (102), 119 (118), 127 (110); II-L-1-6: 42 (47), 99 (96), 86 (80), 101 (102), 114 (117), 105 (121); III-L-1-6: 37 (53), 91 (108), 77 (85), 100 (124), 117 (149), 118 (143); IV-L-1-6: 114 (112), 108 (115), 124 (127), 171 (164), 176 (174), 177 (178).

\section{Female $(n=4)$}

Body. Body features same as male except: P-2 with four dorsal setae; P-3 with three dorsal setae (Fig. 11C); gnathosoma ventral apodeme shorter and thicker (Fig. 11D).

Measurements. Idiosoma L 826 (705-826), W 573 (495-573). Dorsal shield L 691 (585-691), dorsal plate L 652 (551-652), frontal platelets L 146 (131-146). Infracapitular bay depth 176 (136-176); Cx-I

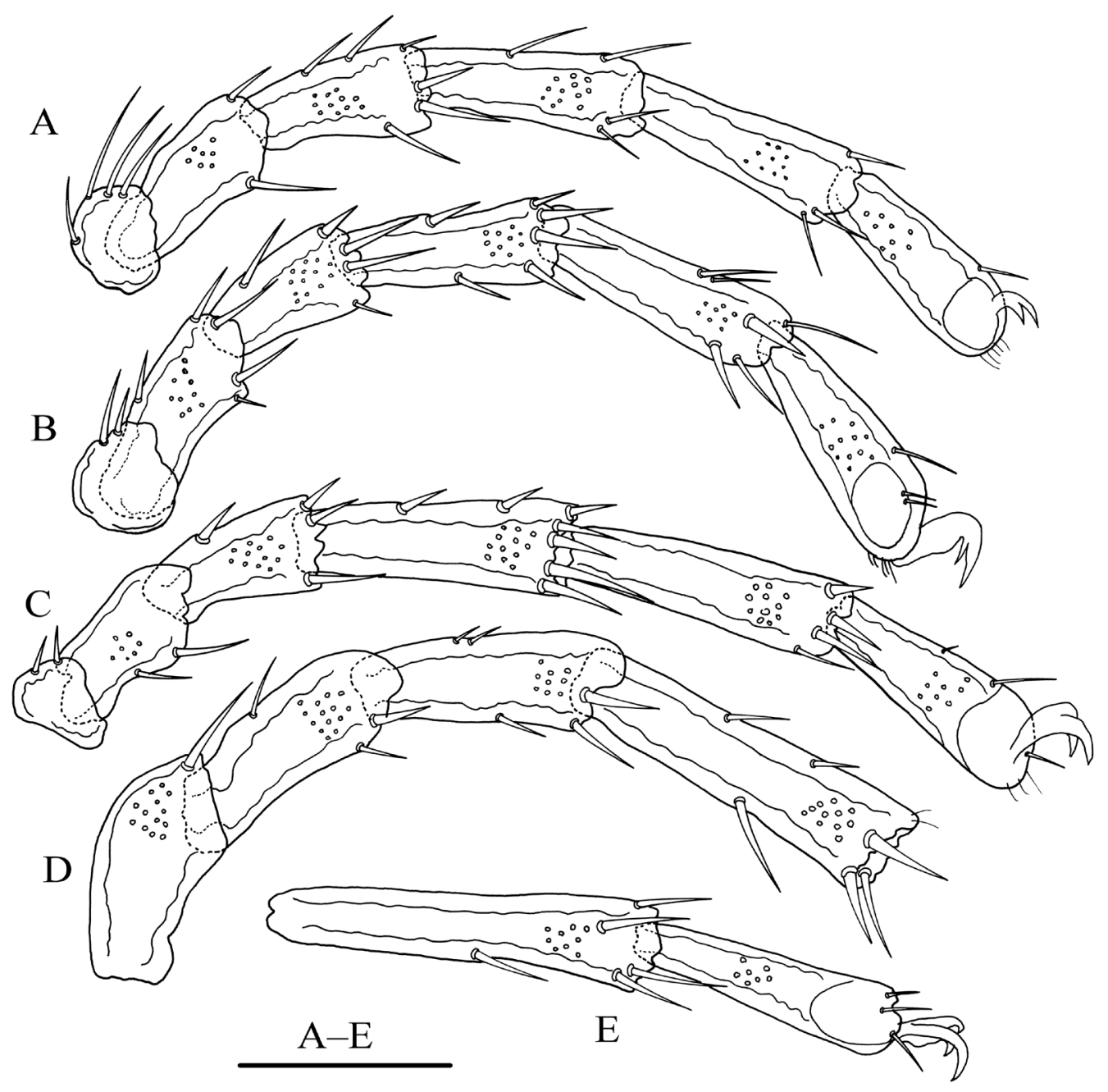

Fig. 12. Torrenticola wuyiensis Gu \& Guo sp. nov.,, , paratype (FJ-TO-20180812). A. leg-I. B. leg-II. C. leg-III. D. leg-IV-1-4. E. leg-IV-5-6. Scale bar $=100 \mu \mathrm{m}$. 
Table 1. Differences in diagnostic characters between Torrenticola wuyiensis sp. nov. and Torrenticola ussuriensis (Sokolow, 1940).

\begin{tabular}{lllll}
\hline & T. wuyiensis sp. nov. & T. ussuriensis (Sokolow, 1940) & \\
\hline & & Russian Far East Japan & Korea \\
$\mathrm{VE}^{1}$ of P-4 & two & four & four & four \\
P-2/P-4 ratio & $1.12-1.24$ & $1.08-1.16$ & 1.50 & 1.05 \\
$E_{4}^{2}$ & $5^{\text {th }}$ & $4^{\text {th }}(\overbrace{}^{\text {th }}), 6^{\text {th }}(+)$ & $5^{\text {th }}$ & $5^{\text {th }}$ \\
Ap \& $V_{2}$ & on the same level & Ap posterior & Ap posterior & on the same level \\
P-3 DE & yes & yes & yes \\
\hline
\end{tabular}

$1=\mathrm{VE}=$ ventral extensions; $2=E_{4}$ on the same line with $\mathrm{n}$ pair of acetabula; $3=\mathrm{DE}=$ distal margin.

L 171 (132-171), mL 136 (119-136), Cx-II-III mL 54 (54-78). Gf L 169 (154-169), W 139 (110139), distance between Gf and Ap 186 (144-186). Gnathosoma vL 363 (323-363), dL 269 (249-269), chelicera bs L 325 (325-378), claw L 63 (59-63). L of palp: P-1, 49 (39-49); P-2, 127 (105-127); P-3, 75 (62-75); P-4, 102 (94-102); P-5, 22 (22-23). L of leg segments: I-L-1-6: 45 (42-45), 100 (95-100), 90 (83-90), 110 (101-110), 117 (109-117), 116 (108-116); II-L-1-6: 47 (45-47), 108 (97-108), 81 (75-81), 113 (99-113), 126 (116-126), 130 (127-130); III-L-1-6: 57 (45-57), 121 (69-121), 92 (8292), 138 (115-138), 154 (144-154), 154 (154-155); IV-L-1-6: 113 (113-116), 122 (111-122), 133 (119-133), 172 (154-172), 185 (177-185), 185 (179-185).

\section{Distribution}

China (Wuyishan).

\section{Habitat}

Streamlet.

\section{Remarks}

This new species is similar to Torrenticola ussuriensis (Sokolow, 1940) in the shape of the palp and dorsal plates,. T. ussuriensis was originally described by Sokolow (1934) from the Primory Territory in the Russian Far East, and later reported from River Inôzava in Japan (Enami 1940), and from Korea (Pešić et al. 2013). Differences between T. wuyiensis and T. ussuriensis are given in Table 1.

\section{Torrenticola dentifera Wiles, 1991}

Figs 13-16

\section{Material examined}

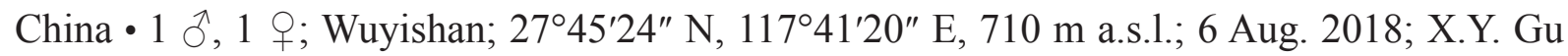
leg.; FJ-TO-20180806 to FJ-TO-20180807.

\section{Description}

Male ( $(n=1)$

Body. Idiosoma elliptical, L/W ratio 1.7 (Fig. 13A). Dorsal plate arrangement: 4+1. Infracapitular bay V-shaped, $\mathrm{Cx}$-II-III $\mathrm{mL}$ relatively long; $L_{4}$ on same line with $2^{\text {nd }}$ pair of acetabula; $E_{4}$ on same line with $5^{\text {th }}$ pair of acetabula; $V_{1}, V_{2}$ anterior to Ap (Fig. 13B). Gnathosoma dorsal apodeme short, ventral apodeme long and blunt, ventral edge of infracapitulum flat. Basal part of gnathosoma very long 
(Fig. 13D). Palp: P-1 short, with one dorsal seta; P-2 with four dorsal setae and one ventral seta at base of ventrodistal extension, which is long and finely serrated; P-3 with two dorsal setae and one ventral seta on serrated ventral extension; P-4 with one dorsal seta and two sharp ventral extensions, bearing three setae (Fig. 13C). Legs I-IV as shown in Fig. 14A-D: claw of Leg-I damaged.

Measurements. Idiosoma L 584, W 338; dorsal shield L 480, W 300, dorsal plate L 425, frontal platelets L 115, shoulder platelets L 143. Infracapitular bay L 119; Cx-I L 166, mL 74, Cx-II-III mL 92; Gf L 105, W 92, distance between Gf and Ap 144. Gnathosoma vL 240, dL 202, chelicera bs L 222, claw L

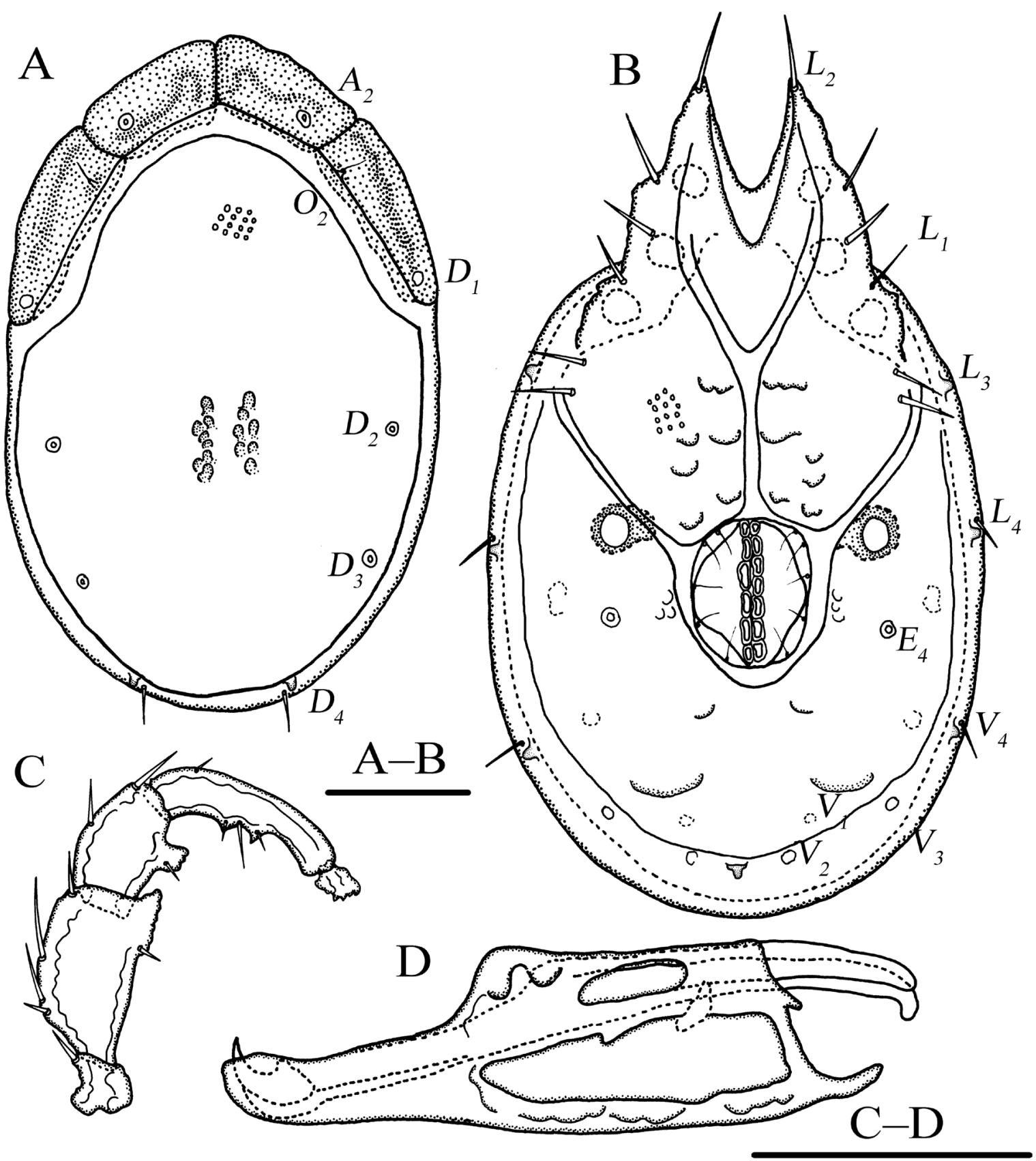

Fig. 13. Torrenticola dentifera Wiles, 1991, đ̊ (FJ-TO-20180806). A. Dorsal view. B. Ventral view. C. Palp, lateral view. D. Infracapitulum and chelicera. Scale bars $=100 \mu \mathrm{m}$. 
29. Ejaculatory complex (Fig. 14E), L 140, aL 91. L of palp: P-1, 23; P-2, 63; P-3, 47; P-4, 86; P-5, 13. L of leg segments: I-L-1-6: 23, 46, 51, 67, 75, 86; II-L-1-6: 24, 57, 43, 57, 61, 73; III-L-1-6: 33, 57, 48, 69, 72, 82; IV-L-1-6: 88, 72, 81, 96, 101, 93.

Female $(\mathbf{n}=1)$

Body. Body features same as male except: $L_{4}$ on the same line with $3^{\text {rd }}$ pair of acetabula. Legs I-IV as shown in Fig. 16A-D: claw of Leg-III damaged.

Measurements. Idiosoma L 602, W 371. Dorsal shield L 483, W 320, dorsal plate L 437, frontal platelets L 116, shoulder platelets L 147. Infracapitular bay depth 120; Cx-I L 160, mL 68, Cx-II-III mL 91. Gf L 128, W 111, distance between Gf and Ap 154. Gnathosoma vL 256, dL 214, chelicera bs L 243, claw L 33. L of palp: P-1, 22; P-2, 66; P-3, 48; P-4, 81; P-5, 13. L of leg segments: I-L-1-6: 25, 55, 51, 67, 79, 85; II-L-1-6: 25, 49, 50, 58, 64, 75; III-L-1-6: 27, 58, 51, 72, 80, 77; IV-L-1-6: 91, 74, 85, 102, 101, 99.

\section{Distribution}

Malaysia (Wiles 1991, 1997), Korea (Pešić et al. 2013), China (new record).

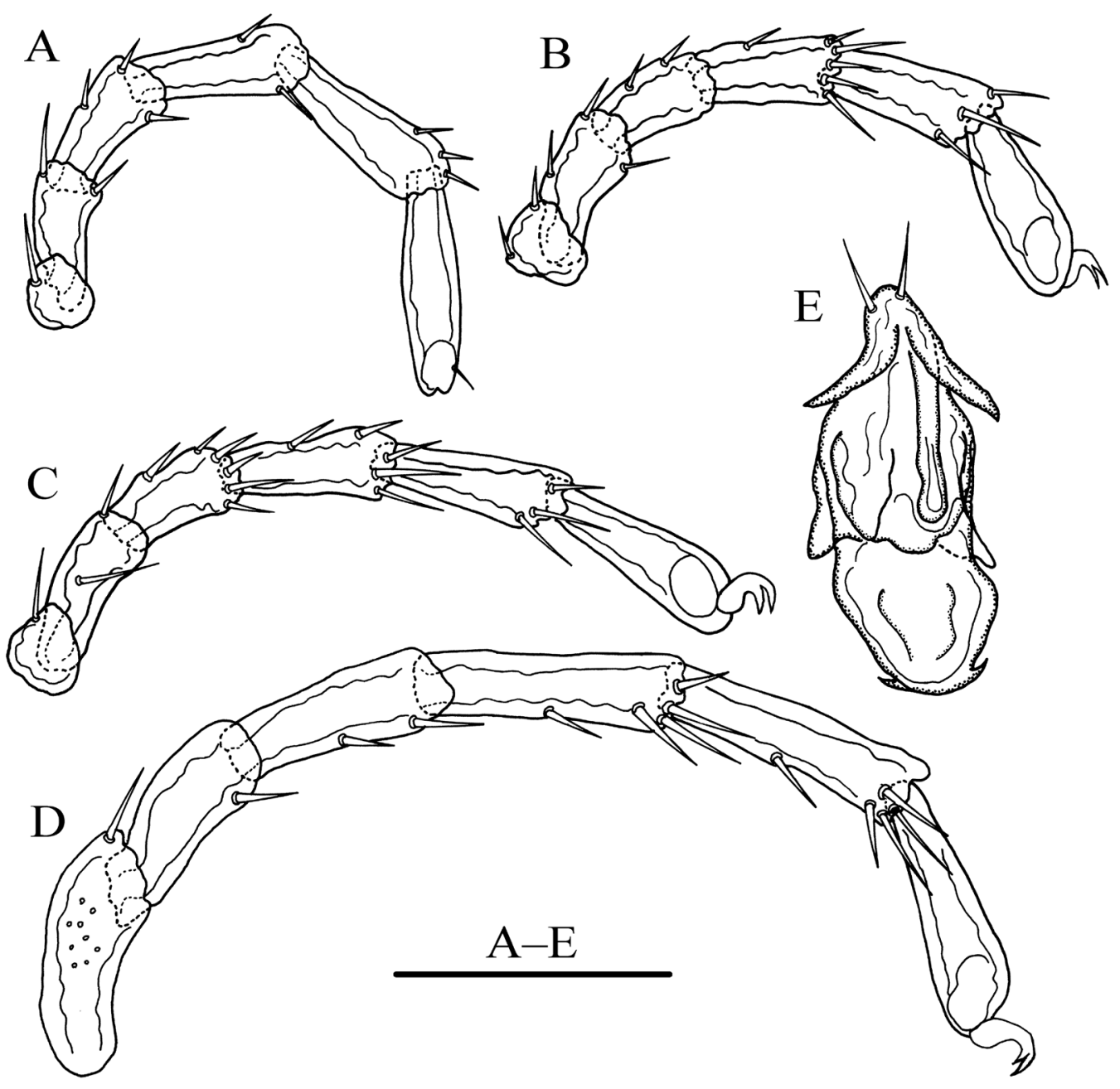

Fig. 14. Torrenticola dentifera Wiles, 1991, Ô, (FJ-TO-20180806). A. leg-I. B. leg-II. C. leg-III. D. legIV. E. Ejaculatory complex. Scale bar $=100 \mu \mathrm{m}$. 


\section{Habitat}

Streamlet.

\section{Remarks}

The Chinese specimens well fit with the original description of Torrenticola dentifera Wiles, 1991, described from Malaysia (Wiles 1991), and later reported from Korea (Pešić et al. 2013). The only

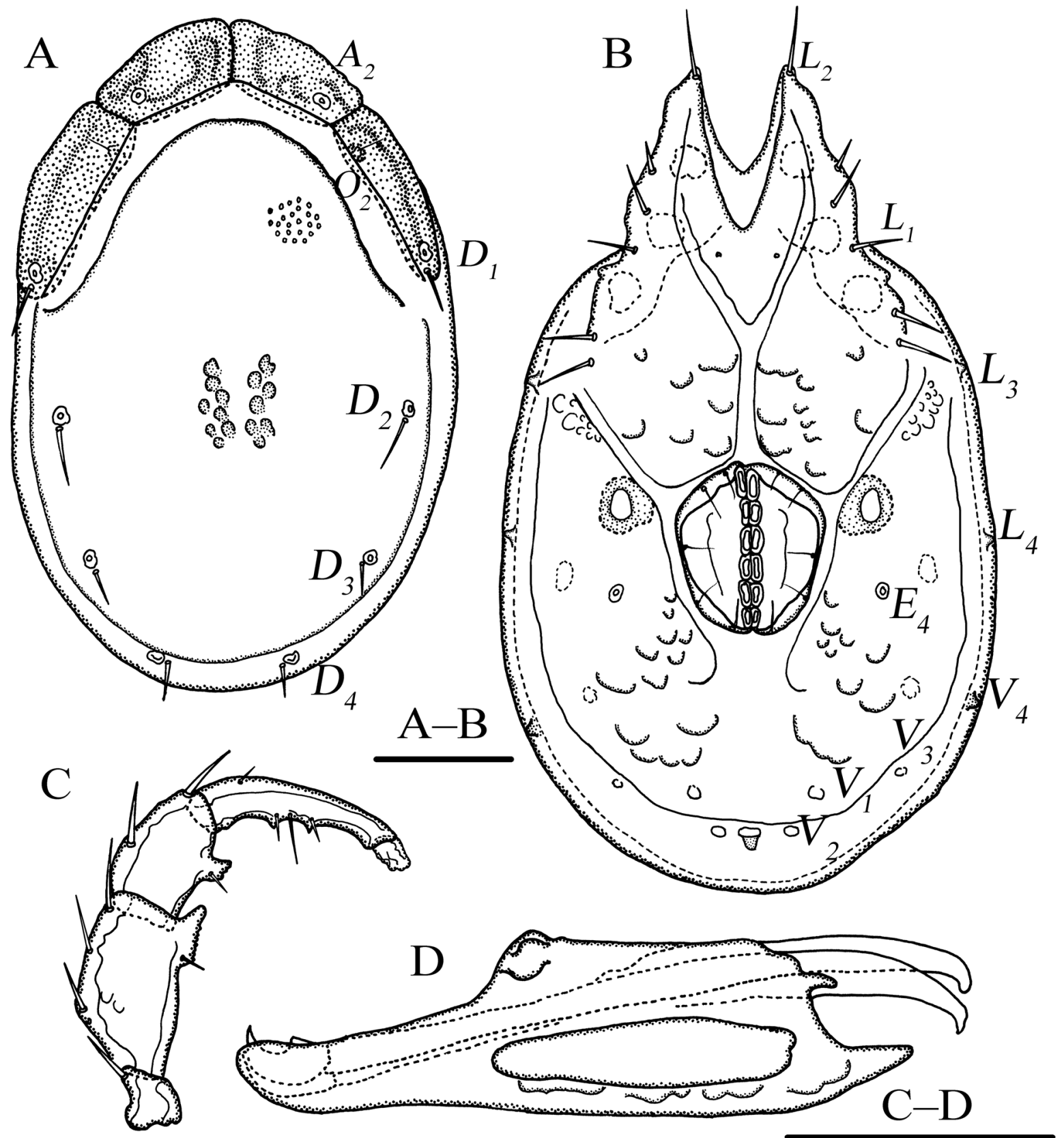

Fig. 15. Torrenticola dentifera Wiles, 1991, $q$, (FJ-TO-20180807). A. Dorsal view. B. Ventral view. C. Palp, lateral view. D. Infracapitulum and chelicera. Scale bars $=100 \mu \mathrm{m}$. 
difference is the specimens from Malaysia and Korea have one large blunt spine at dorsodistal extremity of P-4, but absent in Chinese specimens.

Key to the known species of the family Torrenticolidae in China. (Updated Gu \& Guo 2019 and Gu et al. 2019)

3. Infracapitulum dorsal apodeme short, P-2 and P-3 with obvious ventral protrusions or hyaline expansions (Genus Torrenticola)

- Infracapitulum dorsal apodeme long, P-2 and P-3 without projections on ventral side (Genus Monatractides)

4. Dorsal plate arrangements: $4+1$

- Dorsal plate arrangements: $2+1,2+2 p+1$

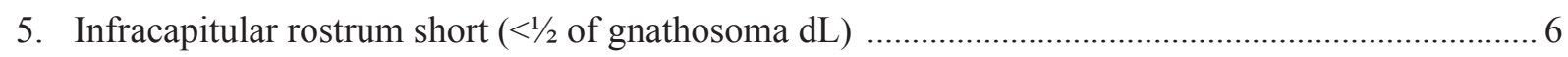

- Infracapitular rostrum long $(\geq 1 / 2$ of gnathosoma $d L)$

6. Palp relatively thin and long 7

- Palp robust and compact, P-2 shorter than P-4, Cx-IV with a prominent suture line of starting at right angle from genital field, laterally curved anteriorly T. nanshihensis Pešić et al.

7. P-3 with a very long tapering ventral projection 8

- P-3 with a triangular, relatively short ventral projection 9
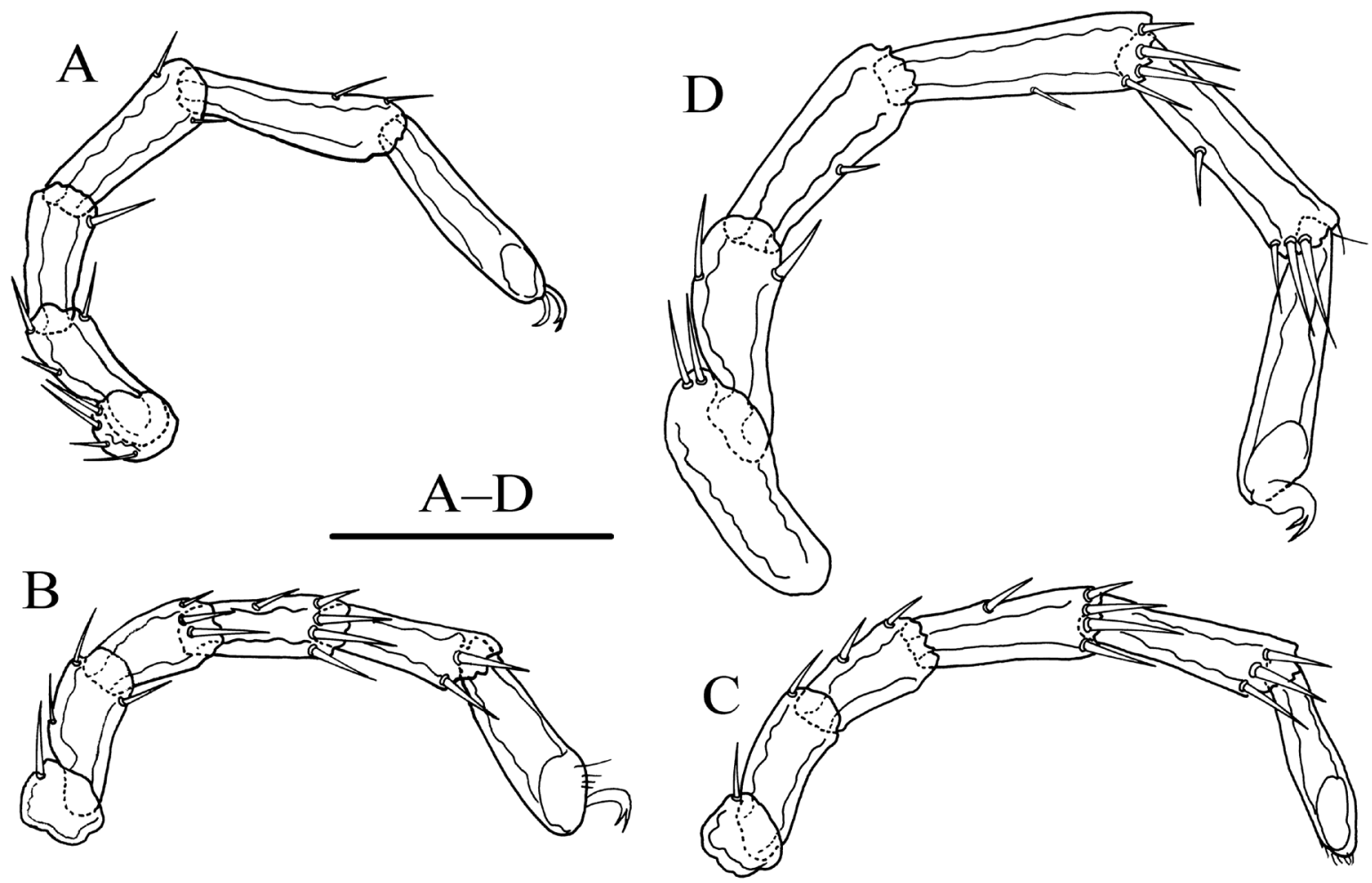

Fig. 16. Torrenticola dentifera Wiles, 1991, , (FJ-TO-20180807). A. leg-I. B. leg-II. C. leg-III. D. legIV. Scale bar $=100 \mu \mathrm{m}$. 
GU X.-Y. et al., New species and new record of Torrenticolidae from China

8. $\mathrm{P}-2$ and $\mathrm{P}-3$ with the smooth and sharp ventral extension

T. projectura Pešić et al.

- P-2 and P-3 with the serrated ventral extension T. dentifera Wiles, 1991

9. Infracapitular bay deep, ventral apodeme $\mathrm{L}$ about two times of dorsal apodeme 10

- Infracapitular bay shallow, ventral apodeme L three times longer than dorsal apodeme

T. curta Jin, 1997

10. Idiosoma roundish, the lateral view of infracapitulum acute triangle-like

T. siamis Pešić \& Smit, 2009

- Idiosoma elliptical, infracapitulum regular triangle-like in the lateral view

T. trigona Gu \& Guo, 2019

11. Ventral extensions of $\mathrm{P}-2, \mathrm{P}-3$ serrate

- Ventral extensions of P-2, P-3 smooth

12. Dorsal apodeme of infracapitulum with a fine spine, AP close to the line of primary sclerotization, $E_{4}$ at the same level as the $3^{\text {rd }}$ pair of acetabula ....... T. yanjinensis Jin, 1997

- Dorsal apodeme of infracapitulum with a broad spine, AP on the line of primary sclerotization, $E_{4}$ at the same level as the $4^{\text {th }}$ pair of acetabula

T. dentipalpis Jin, 1997

13. The concavity between the ventral prolongations of P-4 small, idiosoma elliptical 14

- The concavity between the ventral prolongations of P-4 big and obvious, idiosoma oblate T. fodingensis $\mathrm{Gu} \&$ Guo, 2018

14. Ap anterior to $V_{2}$

- Ap on the line with $V_{2}$ or posterior to $V_{2}$ 16

15. P-2 longer than $1 / 3$ total palp L, gnathosoma elongated, vL 308-381, dL 263-30

T. tenuichelicera $\mathrm{Gu} \& \mathrm{Guo}, 2018$

- P-2 shorter than $1 / 3$ total palp L, gnathosoma normal, vL 284-302, dL 229-231

T. nipponica (Enami, 1940)

16. Ap on the line with $V_{2}$, shoulder platelets normal

- Ap posterior to $V_{2}$, shoulder platelets offset to the inside

T. hainanensis Gu \& Guo, 2019

17. P-2 with a laterally compressed and apically serrated ventrodistal extension, spine-like

..T. spinextension Gu \& Guo sp. nov.

- P-2 with a small sharp ventrodistal extension T. tetrapora Viets, 1935

18. Dorsal plate arrangements: $2+2 \mathrm{p}+1$

- Dorsal plate arrangements: 2+1, P-3 distal margin with denticles, P-4 stocky T. taiwanicus Pešić et al.

19. Infracapitular rostrum short $(<1 / 2$ of gnathosoma $d L)$ 20

- Infracapitular rostrum long $(\geq 1 / 2$ of gnathosoma $\mathrm{dL}$ T. suptilisrostrum Gu \& Guo sp. nov.

20. About $3 / 4$ of shoulder platelet fused with the large dorsal plate, posterior suture line of Cx-I retrogressive

T. postfusina Gu \& Guo 2019

- About $1 / 2$ of shoulder platelet fused with the large dorsal plate, posterior suture line of Cx-IV obvious and long

T. wuyiensis Gu \& Guo sp. nov. 


\section{Remark}

Torrenticola semicolor Viets, 1977 and Torrenticola alargada Goldschmidt, 2007, reported to be new records to Chinese fauna, were rechecked to be mis-determinated. So they are not included in the key.

\section{Discussion}

As a result of human production and living behaviors, the environment has been severely deteriorated, especially water pollution has caused damage to various water ecosystems and greatly reduced species diversity. Torrenticolid water mites live in different running waters, and are possible monitoring organisms of water quality (Goldschmidt 2009, 2016). Therefore, it is critical to investigate the diversity of Torrenticolidae.

At present, there are more than 600 torrenticolid species described all over the world, but only 28 species in China. And even in China, more than 50\% of these species are found in Southwest China (Gu \& Guo 2019). So in the near future, species identification of torrenticolid water mites is still one of the biggest problems to be resolve in China. Further survey of water mites should be carried out to the other regions in China.

\section{Acknowledgments}

This research was supported by National Natural Science Foundation of China No. 31772421, 31750002, Guizhou Science and Technology Project No. Qiankehe Pingtai Rencai [2017]5788, Guizhou Graduate Research Fund Project No. Qianjiaohe YJSCXJH [2019]105, Xinyao Gu (CSC201906670003) is supported by the scholarship from China Scholarship Council.

\section{References}

Enami M. 1940. Water mites from Izu. I. Rheophilous water mites from river Inôzawa. To hoku Daigaku. Science reports of Tôhoku University (Series 4, Biology) 15: 225-229.

Goldschmidt T. 2007. Studies on Latin American water mites of the genus Torrenticola Piersig, 1896 (Torrenticolidae, Hydrachnidia, Acari). Zoological Journal of the Linnean Society 150: 443-678. https://doi.org/10.1111/j.1096-3642.2007.00305.x

Goldschmidt T. 2009. Water mites (Acari, Hydrachnidia) in tropical springs - diversity, specificity, monitoring possibilities. Internationale Vereinigung für theoretische und angewandte Limnologie: Verhandlungen 30 (5): 669-672. https://doi.org/10.1080/03680770.2009.11902212

Goldschmidt T. 2016. Water mites (Acari, Hydrachnidia): powerful but widely neglected bioindicators a review. Neotropical Biodiversity 2 (1): 12-25. https://doi.org/10.1080/23766808.2016.1144359

Gu X.Y. \& Guo J.J. 2019. Five new species of genera Torrenticola and Monatractides (Acari, Hydrachnidia, Torrenticolidae) from Hainan Island, China. Systematic and Applied Acarology 24 (12): 2460-2482. https://doi.org/10.11158/saa.24.12.12

Gu X.Y., Jin D.C., Yi T.C. \& Guo J.J. 2019. Contributions to the knowledge of Torrenticolid water mites (Acari: Hydrachnidia) in Doupengshan, China. Zootaxa 4695 (2): 101-121.

https://doi.org/10.11646/zootaxa.4695.2.1

Jin D.C. 1997. Hydrachnellae-morphology systematics a primary study of Chinese fauna. Guizhou Science and Technology Publishing House, Guiyang.

Martin P.A. 2009. Redescription of Torrenticola (Megapalpis) fagei (E. Angelier, 1949) (Acari, Hydrachnidia). Lauterbornia, 67: 183-188. 
Pešić V., Semenchenko K.A. \& Lee W. 2013. Torrenticolid water mites from Korea and the Russian Far East. ZooKeys 299: 21-48. https://doi.org/10.3897/zookeys.299.5272

Pešić V. \& Smit H. 2014. Torrenticolid water mites (Acari: Hydrachnidia: Torrenticolidae) from Malaysian Borneo. Zootaxa 3840 (1): 59-60. https://doi.org/10.11646/zootaxa.3840.1.1

Sokolow I. 1934. Beiträge zur Kenntnis der Hydracarinenfauna des Ussuri Gebietes II. Hydracarinen der fließenden Gewässer. Zoologische Jahrbücher, Abteilung für Systematik, Ökologie und Geographie der Tiere 65: 309-388.

Wiles P.R. 1991. Rheophilic watermites (Acari: Hydrachnidia) from mainland Malaysia. Acarologia 32 (1): 41-56.

Wiles P.R. 1997. Asian and Oriental Torrenticolidae Piersig, 1902 (Acari: Hydrachnidia: Lebertioidea): a revision of the family and description of new species of Torrenticola Piersig and Pseudotorrenticola Walter, from Southeast Asia. Journal of Natural History 31: 191-236.

https://doi.org/10.1080/00222939700770121

Zhang Z.Q. 2018. Repositories for mite and tick specimens: acronyms and their nomenclature. Systematic and Applied Acarology 23 (12): 2432-2446. https://doi.org/10.11158/saa.23.12.12

Manuscript received: 17 December 2019

Manuscript accepted: 6 March 2020

Published on: 10 April 2020

Topic editor: Rudy Jocqué

Desk editor: Eva-Maria Levermann

Printed versions of all papers are also deposited in the libraries of the institutes that are members of the EJT consortium: Muséum national d'histoire naturelle, Paris, France; Meise Botanic Garden, Belgium; Royal Museum for Central Africa, Tervuren, Belgium; Royal Belgian Institute of Natural Sciences, Brussels, Belgium; Natural History Museum of Denmark, Copenhagen, Denmark; Naturalis Biodiversity Center, Leiden, the Netherlands; Museo Nacional de Ciencias Naturales-CSIC, Madrid, Spain; Real Jardín Botánico de Madrid CSIC, Spain; Zoological Research Museum Alexander Koenig, Bonn, Germany; National Museum, Prague, Czech Republic. 